\title{
Yields and Quality of Italian Ryegrass (Lolium multiflorum) and Common Vetch (Vicia sativa) Grown in Monocultures and Mixed Cultures under Irrigated Conditions in the Highlands of Madagascar
}

\author{
Volatsara B. Rahetlah ${ }^{1}$, Jean M. Randrianaivoarivony ${ }^{1}$, Blandine Andrianarisoa ${ }^{2}$, \\ Lucile H. Razafimpamoa ${ }^{1} \&$ Vololoniaina L. Ramalanjaona $^{1}$ \\ ${ }^{1}$ FIFAMANOR (Centre de Développement Rural et de Recherche Appliquée), Antsirabe, Madagascar \\ ${ }^{2}$ Laboratoire de Biotechnologie et Microbiologie, Faculté des Sciences, Antananarivo, Madagascar \\ Correspondence: Volatsara B. Rahetlah, FIFAMANOR, Antsirabe, Madagascar. Tel: 262-204-499-139. E-mail: \\ volats@yahoo.fr
}

Received: March 7, 2012 Accepted: August 20, 2012 Online Published: September 1, 2012

doi:10.5539/sar.v2n1p15

URL: http://dx.doi.org/10.5539/sar.v2n1p15

\begin{abstract}
A field experiment was conducted under irrigated conditions in the highlands of Madagascar to assess the potential of intercropping Italian ryegrass with common vetch for improving yield and quality of forage. Seed proportions studied were ryegrass-vetch 100:0; 0:100; 50:33; 50:50; 50:66; 75:33 and 75:66. Mixtures were sown in alternate rows and the sowing rates of pure stands of ryegrass and vetch were 20 and $60 \mathrm{~kg}$ per hectare, respectively. The results showed that all mixtures achieved yield advantage over pure stands with the highest land equivalent ratio value for dry matter yield obtained from the mixture of 75:66 (1.47) followed by 50:50 (1.35). Slight increase of crude protein content and protein digested in the small intestine when rumen-fermentable nitrogen is limiting (PDIN) content were obtained from mixtures compared with pure stand of ryegrass. Vetch rate in dry matter yield of mixtures increased with the increase of vetch seed proportion and ranged from 31 to $44 \%$. Agressivity and competitive ratio indices showed that ryegrass was slightly competitive than vetch. Intercropping Italian ryegrass with common vetch at the seed proportions of 75:66 or 50:50 could be a more sustainable alternative cropping to alleviate dry season feed shortages of dairy livestock in the highlands of Madagascar.
\end{abstract}

Keywords: yield, quality, ryegrass, vetch, inter-cropping, forage, competition

\section{Introduction}

Dairy farming is an important source of incomes for mixed crop-livestock smallholder farmers in the central highlands of Madagascar (Raharimalala, 2002). Despite significant increase of global milk production over the last four decades, estimated to vary from 200, 000 litres in 1972 to 32,000,000 litres in 2006 for the Vakinankaratra region which produces more than $80 \%$ of the total production, cow productivity remains low, averaging 2,500 litres per year (Raharimalala, 2002; Lecomte, Duteurtre, \& Tillard, 2008). One of the main limiting factors for increasing production and productivity of dairy livestock is feed shortage in both quality and quantity especially during the dry and cool season. Dairy cattle under zero-grazing system are mainly fed on natural, cultivated fodder plants and crop residues (Rakotondramanana, 1999; Rasambainarivo et al., 2000). During the five to six months dry and cool season, significant decrease of milk yield is mainly attributed to the lower quality of the diet primarily composed of crop residues especially rice straw.

The feed shortage problem is being exacerbated by soil degradation, high input costs and effects of climatic variations (Vågen, Walsh, \& Shepherd, 2006). An alternative option to alleviate deficiencies in quality and quantity of the forage component of the diet, in a more sustainable way, is the development of grass-legume mixtures (Whiteman, 1980; Adesogan, Salawu, \& Deaville, 2000). Potential benefits arising from grass-legume associations include increased crop productivity through enhanced soil fertility and efficient use of growth resources and improved forage quality through complementary effects of the combined species (Yildirim \& Guvence, 2005; Lithourgidis, Vasilakoglou, Dhima, Dordas, \& Yiakoulaki, 2006; Dhima, Lithourgidis, Vasilakoglou, \& Dordas, 2007; Bingol, Karsli, Yilmaz, \& Bolat, 2007). Italian ryegrass (Lolium multiflorum L.) is a widely grown off-season forage crops in the highlands of Madagascar. It is cultivated under irrigated conditions 
in pure stand or in mixture with fodder oat on rice land (Rakotondramanana, 1999). Common vetch (Vicia sativa L.), has been recently identified as a potential forage legume suitable for winter fodder production (Lecomte et al., 2008). The present study aimed to assess the potential of intercropping Italian ryegrass with common vetch for improving yield and quality of forage.

\section{Material and Methods}

\subsection{Experimental Sites}

The field experiment was carried out under surface-irrigated conditions at two agro-ecological zones of the Vakinankaratra region, Belazao, Antsirabe II district (19 90'S - 46 97'E, 1571m) and Andranomafana, Betafo district $\left(19^{\circ} 83^{\prime} \mathrm{S}-46^{\circ} 83^{\prime} \mathrm{E}, 1310 \mathrm{~m}\right)$, respectively, during the dry and cool season (June to September) of 2010. The Vakinankaratra region has tropical altitude climate with a dry and cool season lasting from May to September and a warm and wet season extending from October to April with annual mean rainfall of $1300 \mathrm{~mm}$. Soil types at the two sites are humic hydromorphic and tropical brown of volcanic origin, respectively (Balasubramanian, Ratsimandresy, Razafinjara, \& Rabeson, 1994).

\subsection{Treatments and Experimental Design}

The experiment was laid out in a randomized complete block design with four replicates. Treatments were consisted of seed proportions of Italian ryegrass (cv. Tama) and common vetch (cv. ILRI 5127D) as follows: 100:0 (100\% ryegrass), 0:100 (100\% vetch), 50:33 (50\% ryegrass $+33 \%$ vetch $), 50: 50(50 \%$ ryegrass $+50 \%$ vetch), $50: 66$ (50\% ryegrass $+66 \%$ vetch), $75: 33(75 \%$ ryegrass $+33 \%$ vetch $)$, and $75: 66(75 \%$ ryegrass $+66 \%$ vetch) based on pure stands sowing rates, respectively. Mixtures were sown in alternate rows and the sowing rates of pure stands of ryegrass and vetch were 20 and $60 \mathrm{~kg}$ per hectare, respectively. Each plot measured $3 \mathrm{~m} \mathrm{x}$ $2 \mathrm{~m}$ with 10 rows of $3 \mathrm{~m}$ length spaced with $0.2 \mathrm{~m}$ between rows. Fertilizer composed of $36 \mathrm{~kg} \mathrm{~N}$ and $92 \mathrm{~kg} \mathrm{P}_{2} \mathrm{O}_{5}$ in the form of diaminophosphate and $48 \mathrm{~kg} \mathrm{~K}_{2} \mathrm{O}$ in the form of potassium chloride and 20 tons of cattle manure $\mathrm{ha}^{-1}$ was broadcasted and incorporated into the soil of all plots at the time of sowing. Additional nitrogen fertilizer in the form of urea at $46 \mathrm{~kg} \mathrm{~N} \mathrm{ha}^{-1}$ was applied in two-splits 30 days after sowing and following the first cut, respectively.

\subsection{Sampling and Chemical Analysis}

Pure stands and mixtures were cut two times, 10 and 16 weeks after sowing, respectively. Green matter (GM) yield was estimated by cutting herbage from $2 \mathrm{~m} \times 1 \mathrm{~m}$ quadrat in the inner rows of each plot. Ryegrass height and tiller numbers were measured on eight randomly selected plants within quadrat, 30 days after sowing and prior to the first cutting. Sub-samples (800 to $1000 \mathrm{~g}$ wet weight) were taken from the harvested herbage and oven-dried at $60^{\circ} \mathrm{C}$ for 72 hours for dry matter content determination and chemical analysis. Dried forage subsamples were ground to pass through a $1 \mathrm{~mm}$ sieve for proximate analysis and a $2 \mathrm{~mm}$ sieve for rumen degradation study (Association of Official Analytical Chemists [AOAC], 1990). Forage quality parameters estimated were total ash (TA), crude protein (CP), crude fibre (CF), energy unit effectively available to the animal (feed unit for lactation, UFL), protein digested in the small intestine when rumen-fermentable nitrogen is limiting (PDIN), and protein digested in the small intestine when rumen-fermentable energy is limiting (PDIE). Total ash content was determined by incinerating dried samples in a muffle furnace at $550^{\circ} \mathrm{C}$ for six hours. The nitrogen content was estimated using the Kjeldahl method (AOAC, 1990) and the crude protein content was calculated by multiplying the $\mathrm{N}$ content by 6.25 . Crude fibre content was determined by the Weende method and the UFL, PDIN, and PDIE contents were determined according to nylon bag technique (AOAC, 1990).

Forage quality parameters yields were calculated by multiplying dry matter yield by forage quality parameters contents.

\subsection{Competition Indices}

Land equivalent ratio (LER), aggressivity (A) and competitive ratio (CR) indices were calculated to assess the effect of competition between the two species in mixtures and the yield advantage of intercropping over sole cropping. LER indicates the efficiency of intercropping for using the resources of the environment compared to sole cropping (Mead \& Wiley, 1980). LER value exceeding unity indicates that the intercropping favours the growth and yield of the species (Caballero, Goicoechea, \& Hernaiz, 1995). In contrast, LER value lesser than unity indicates negative effects of intercropping for the growth and yield of the species grown in mixture. Aggressivity index is often used to indicate, through measuring of relative yield increase, the competitive relationship between two crops in mixed cropping (McGilchrist, 1965). If the value of A is zero, both crops are equally competitive. If the value of Aryegrass is positive then ryegrass is dominant over vetch, if Aryegrass is negative, ryegrass is dominated by vetch. The reverse is true for Avetch. CR is another index used to assess competitive ability of 
crops in mixtures (Wiley \& Rao, 1980). The CR represents the ratio of LERs for the individual crops and takes into account the proportion of the crops in which they are initially sown. If CR ryegrass is greater than one, ryegrass is more competitive than vetch, and if the value is lesser than one, then ryegrass is less competitive than vetch. The reverse is true for CR vetch.

Competition indices were calculated by the following formula:

$$
\mathrm{LER}=\{\mathrm{La}+\mathrm{Lb}\}=[(\mathrm{Yab} / \mathrm{Yaa})+(\mathrm{Yba} / \mathrm{Ybb})]
$$

where $\mathrm{La}$ and $\mathrm{Lb}$ are the LER for rygrass and vetch crops, repectively, Yab and Yba are the individual intercrop yields and Yaa and Ybb are the individual pure stand yields (Wiley, 1979).

$$
\begin{gathered}
\text { Aryegrass }=\{\mathrm{Yab} /(\mathrm{Yaa} \times \mathrm{Zab})\}-\{\mathrm{Yba} /(\mathrm{Ybb} \times \mathrm{Zba})\} \\
\text { Avetch }=\{\mathrm{Yba} /(\mathrm{Ybb} \times \mathrm{Zba})\}-\{\mathrm{Yab} /(\mathrm{Yaa} \times \mathrm{Zab})\}
\end{gathered}
$$

where $\mathrm{Zab}$ is the sown proportion of ryegrass in intercropping, $\mathrm{Zba}$ is the sown proportion of vetch in intercropping.

$$
\begin{gathered}
\mathrm{CR} \text { ryegrass }=(\mathrm{La} / \mathrm{Lb})(\mathrm{Zba} / \mathrm{Zab}) \\
\mathrm{CR} \text { vetch }=(\mathrm{Lb} / \mathrm{La})(\mathrm{Zab} / \mathrm{Zba})
\end{gathered}
$$

\subsection{Statistical Analysis}

The recorded data were analyzed with linear mixed model (LMM) procedure using Genstat discovery edition 4 software (Buysse, Stern, \& Coe, 2004). Within the model, blocking factor was considered as random effect.

\section{Results}

\subsection{Plant Height and Tiller Numbers}

In the linear mixed model, measurements of plant height for ryegrass averaged over the two sampling dates showed that the site effect $(p=0.001)$ and the site $x$ seed proportions interaction effect $(p=0.001)$ were significant (Table 1). Means of ryegrass height were significantly higher at the first site (Belazao) compared with the second site (Andranomafana) (Figure 1a). At Belazao, differences in ryegrass height were not significant between pure stand and mixtures. However, the highest ryegrass height value $(42.5 \mathrm{~cm})$ was obtained from the pure stand and the lowest value $(38.50 \mathrm{~cm})$ from the ryegrass-vetch mixture of 50:50. At Andranomafana, significantly higher ryegrass height values were recorded for mixtures compared with pure stand.

Table 1. Results of the linear mixed model analyses. Table of degrees of Freedom (df), F Values (F), P Values (P), and estimated variance components for the linear mixed model

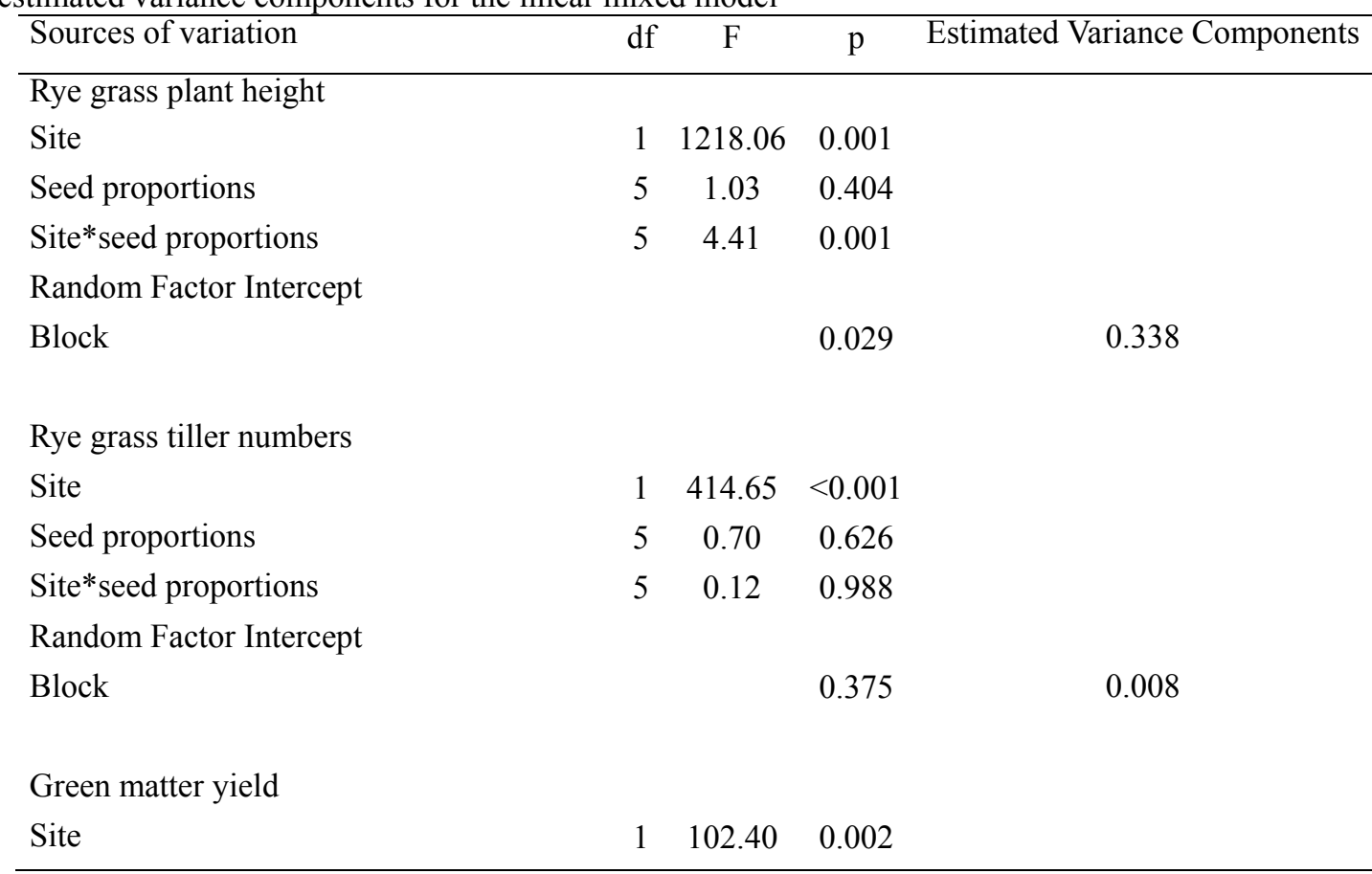




\begin{tabular}{llll}
\hline Seed proportions & 6 & 3.78 & 0.005 \\
Site*seed proportions & 6 & 2.82 & 0.024 \\
Random Factor Intercept & & &
\end{tabular}

Block

0.046

1.350

Dry matter yield

Site

$\begin{array}{lll}1 & 43.82 & 0.007\end{array}$

Seed proportions

$\begin{array}{lll}6 & 9.40<0.001\end{array}$

Site*seed proportions

$\begin{array}{lll}6 & 2.17 & 0.069\end{array}$

Random Factor Intercept

Block

0.040

0.053

Feed unit for lactation yield

Site

$\begin{array}{ccc}1 & 37.96 & 0.009 \\ 6 & 61.19 & <0.001 \\ 6 & 13.67 & 0.058\end{array}$

Seed proportions

$\begin{array}{lll}6 & 13.67 & 0.058\end{array}$

Random Factor Intercept

Block

0.042

0.042

Protein digested in the small intestine yield

Site

$\begin{array}{ccc}1 & 45.46 & 0.007 \\ 6 & 10.21 & <0.001 \\ 6 & 1.97 & 0.096\end{array}$

Seed proportions

$\begin{array}{lll}6 & 1.97 & 0.096\end{array}$

Random Factor Intercept

Block

0.045

232

(a)

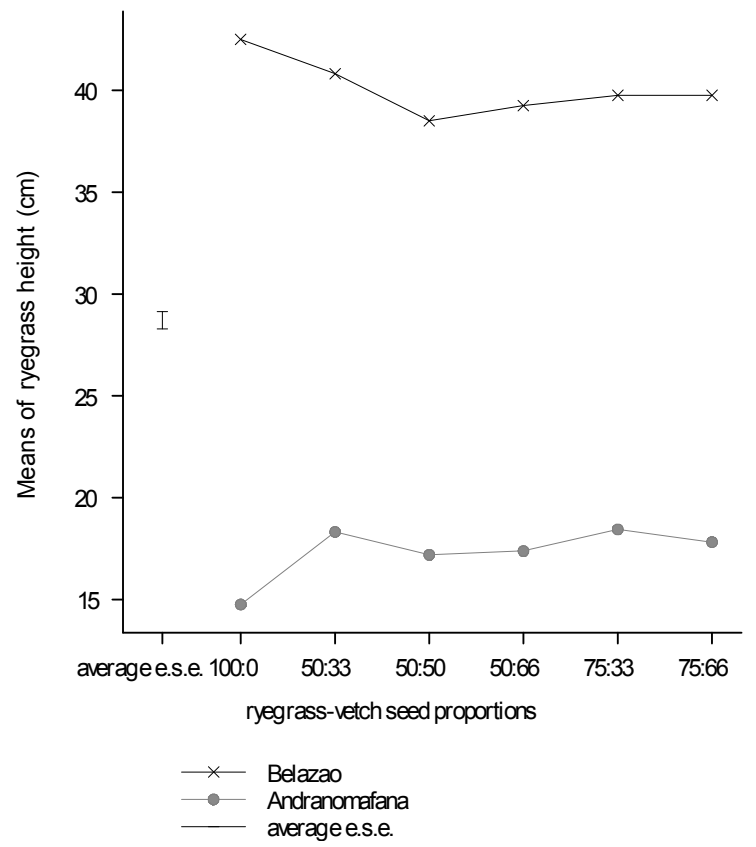

(b)

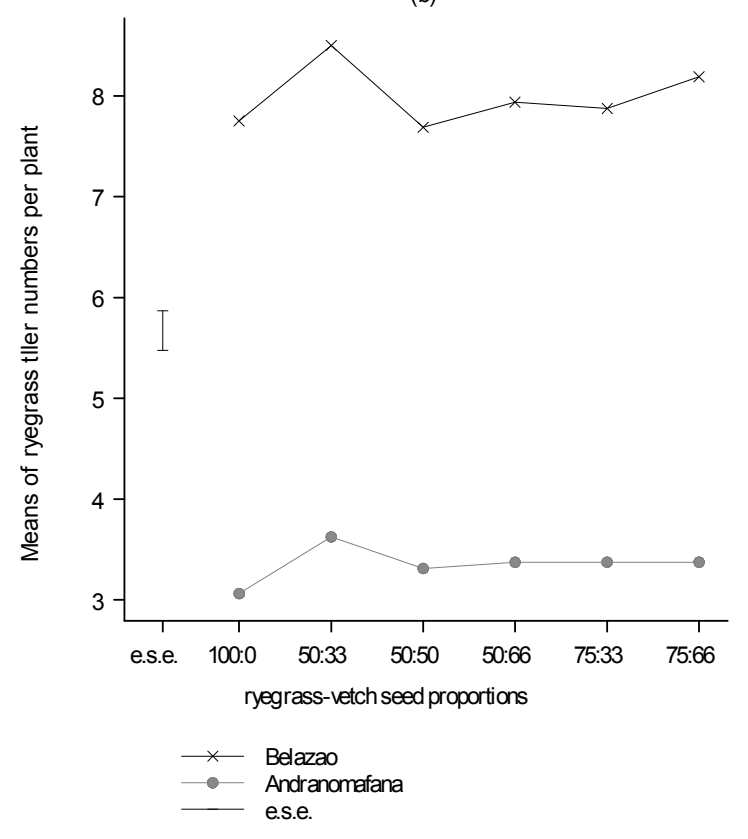

Figure 1. Means +/-e.s.e's for ryegrass height (a) and tiller numbers (b) over the two sampling dates at the two sites 
Average tiller numbers measurements for ryegrass were significantly affected by site $(\mathrm{p}<0.001)$ but not by seed proportions $(p=0.626)$ nor by their interaction $(p=0.988)$ (Table 1). At Belazao, the highest value (8.5) of ryegrass tiller numbers was obtained from the mixture of 50:33 while the lowest value (7.69) was recorded for the mixture of 50:50 (Figure 1b). At Andranomafana, the highest value (3.625) of ryegrass tiller numbers was also achieved by the mixture of 50:33 and the lowest value (5.75) was obtained from pure stand (Figure 1b).

\subsection{Green Matter, DM, UFL and PDI Yields}

Results of the linear mixed model showed significant effects of site $(p=0.002)$, seed proportions $(p=0.005)$ and their interaction $(\mathrm{p}=0.024)$ for green matter yield (Table 1). At Belazao, the highest mean green matter yield (GMY) $\left(24.30 \mathrm{t} \mathrm{ha}^{-1}\right)$ was obtained from the mixture including 50\% ryegrass and 50\% vetch (50:50) while the lowest mean GMY $\left(17.75 \mathrm{t} \mathrm{ha}^{-1}\right)$ was recorded for the mixture of 50:33 (Figure 2a). All mixtures except the mixture of 50:33 gave slightly higher GMY than pure stands of either species. At Andranomafana, the highest mean GMY $\left(12.31 \mathrm{tha}^{-1}\right)$ was recorded for the mixture of 75:66 while the lowest mean GMY $\left(1.76 \mathrm{t} \mathrm{ha}^{-1}\right)$ was obtained from the pure stand of vetch (Figure 2a). All mixtures except the mixture of 50:66 achieved similar GMY compared with pure stand of ryegrass. According to the two site's results average, mean GMY of mixtures were identical compared with pure stand of ryegrass but highly significant compared with pure stand of vetch (Table 2).

Table 2. Growth parameters and yields of ryegrass-vetch pure stands and mixtures

\begin{tabular}{|c|c|c|c|c|c|c|}
\hline $\begin{array}{c}\text { Seed } \\
\text { proportions }\end{array}$ & $\begin{array}{l}\text { Ryegrass } \\
\text { height }(\mathrm{cm})\end{array}$ & $\begin{array}{c}\text { Ryegrass tiller } \\
\text { numbers }\end{array}$ & $\begin{array}{l}\text { Green matter } \\
\text { yield }(\mathrm{t} / \mathrm{ha})\end{array}$ & $\begin{array}{l}\text { Dry matter } \\
\text { yield (t/ha) }\end{array}$ & $\begin{array}{l}\text { UFL yield } \\
\left(\mathrm{x} 10^{3} / \mathrm{ha}\right)\end{array}$ & $\begin{array}{c}\text { PDI yield } \\
\text { (kg/ha) }\end{array}$ \\
\hline $\begin{array}{c}100 \% \\
\text { ryegrass }\end{array}$ & $28.62^{\mathrm{a}^{*}}$ & $5.41^{\mathrm{a}}$ & $14.68^{\mathrm{a}}$ & $3.03^{\mathrm{a}}$ & $2.72^{\mathrm{a}}$ & $195.60^{\mathrm{a}}$ \\
\hline $100 \%$ vetch & - & - & $9.88^{\mathrm{b}}$ & $1.45^{\mathrm{b}}$ & $1.26^{\mathrm{b}}$ & $91.60^{b}$ \\
\hline $\begin{array}{l}50 \% \text { ryegrass } \\
-33 \% \text { vetch }\end{array}$ & $29.56^{\mathrm{a}}$ & $6.06^{\mathrm{a}}$ & $14.03^{\mathrm{a}}$ & $2.58^{\mathrm{a}}$ & $2.27^{\mathrm{a}}$ & $171.80^{\mathrm{a}}$ \\
\hline $\begin{array}{l}50 \% \text { ryegrass } \\
-50 \% \text { vetch }\end{array}$ & $27.84^{\mathrm{a}}$ & $5.50^{\mathrm{a}}$ & $16.88^{\mathrm{a}}$ & $3.17^{\mathrm{a}}$ & $2.82^{\mathrm{a}}$ & $210.00^{\mathrm{a}}$ \\
\hline $\begin{array}{l}50 \% \text { ryegrass } \\
-66 \% \text { vetch }\end{array}$ & $28.31^{\mathrm{a}}$ & $5.66^{\mathrm{a}}$ & $16.21^{\mathrm{a}}$ & $2.95^{\mathrm{a}}$ & $2.58^{\mathrm{a}}$ & $202.80^{\mathrm{a}}$ \\
\hline $\begin{array}{c}75 \% \text { ryegrass } \\
-33 \% \text { vetch }\end{array}$ & $29.09^{\mathrm{a}}$ & $5.62^{\mathrm{a}}$ & $15.81^{\mathrm{a}}$ & $3.05^{\mathrm{a}}$ & $2.70^{\mathrm{a}}$ & $206.10^{\mathrm{a}}$ \\
\hline $\begin{array}{l}75 \% \text { ryegrass } \\
-66 \% \text { vetch }\end{array}$ & $28.78^{\mathrm{a}}$ & $5.78^{\mathrm{a}}$ & $16.38^{\mathrm{a}}$ & $3.45^{\mathrm{a}}$ & $3.16^{\mathrm{a}}$ & $237.30^{\mathrm{a}}$ \\
\hline $\mathrm{SE}( \pm)$ & 0.83 & 0.39 & 1.75 & 0.30 & 0.27 & 20.68 \\
\hline
\end{tabular}

*Within columns means with the same letter are not significantly different $(\mathrm{p}>0.05)$;

$\mathrm{UFL}=$ feed unit for lactation, $\mathrm{PDI}=$ protein digested in the small intestine

The site effect $(p=0.007)$ and the seed proportions effect $(p<0.001)$ were significant for dry matter yield (DMY) but not their interaction $(\mathrm{p}=0.069)$ (Table 1$)$. At Belazao, mean DMY did not vary significantly between seed proportions. The highest mean DMY value $\left(3.80 \mathrm{t} \mathrm{ha}^{-1}\right)$ was obtained from the mixture of 50:50 while the lowest mean DMY value (2.49 $\left.\mathrm{t} \mathrm{ha}^{-1}\right)$ was recorded for the pure stand of vetch (Figure 2b). At Andranomafana, the highest mean DMY value $\left(3.15 \mathrm{tha}^{-1}\right)$ and the lowest mean DMY value $\left(0.405 \mathrm{tha}^{-1}\right)$ were obtained from the mixture of 75:66 and the pure stand of vetch, respectively $(p<0.05)$. Averaged data over the two sites revealed slight increases of DMY in mixtures of 75:66, 50:50 and 75:33 compared with pure stand of ryegrass (Table 2).

Significant effects of site $(p=0.009)$ and seed proportions $(p<0.001)$ were also recorded for UFL yield (Table 1$)$. At Belazao, mean UFL yield was not affected by seed proportions. The highest mean UFL yield $\left(3.41 \times 10^{3}\right.$ units $\left.\mathrm{ha}^{-1}\right)$ and the lowest mean UFL yield $\left(2.17 \times 10^{3}\right.$ units ha $\left.^{-1}\right)$ were obtained from the mixture of 75:66 and the pure stand of vetch, respectively (Figure 2c). At Andranomafana, the mixture of 75:66 gave the highest mean UFL yield $\left(2.897 \times 10^{3}\right.$ units $\left.\mathrm{ha}^{-1}\right)$ but the difference was not significant compared with the pure stand of ryegrass 
$\left(2.591 \times 10^{3}\right.$ units $\left.\mathrm{ha}^{-1}\right)$. Averaged data over the two sites showed higher but not statistically significant values of UFL yields for mixtures of 75:66 and 50:50 compared with pure stand of ryegrass (Table 2).

(a)

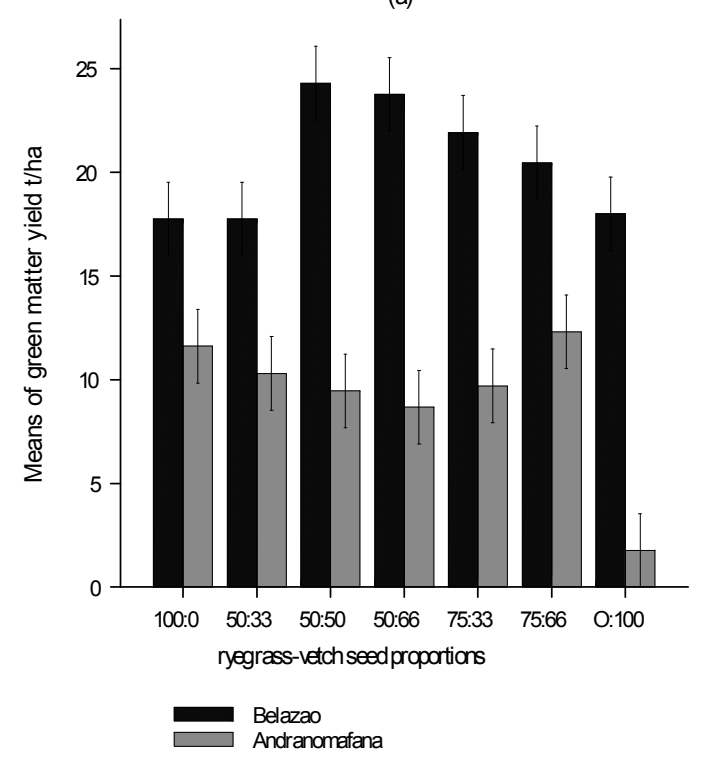

(c)

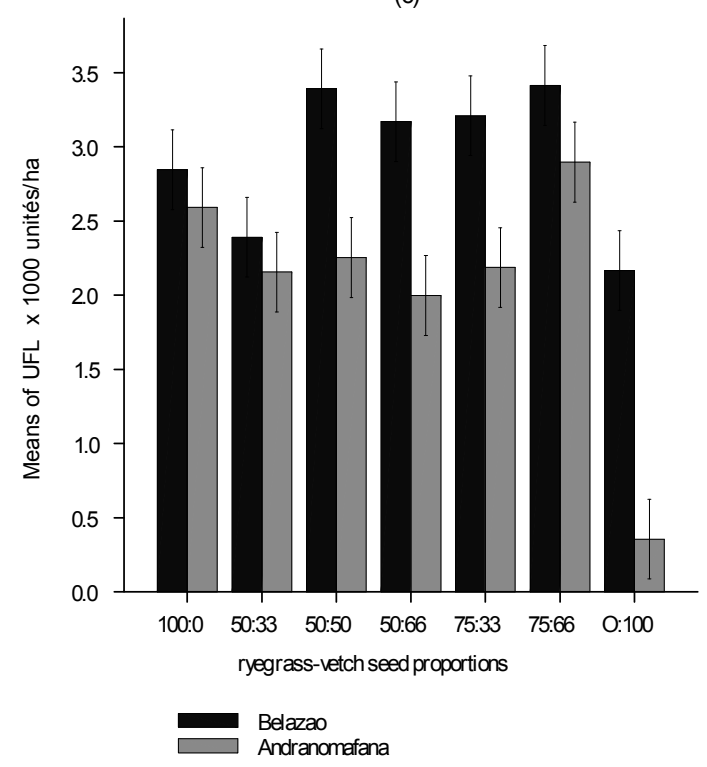

(b)

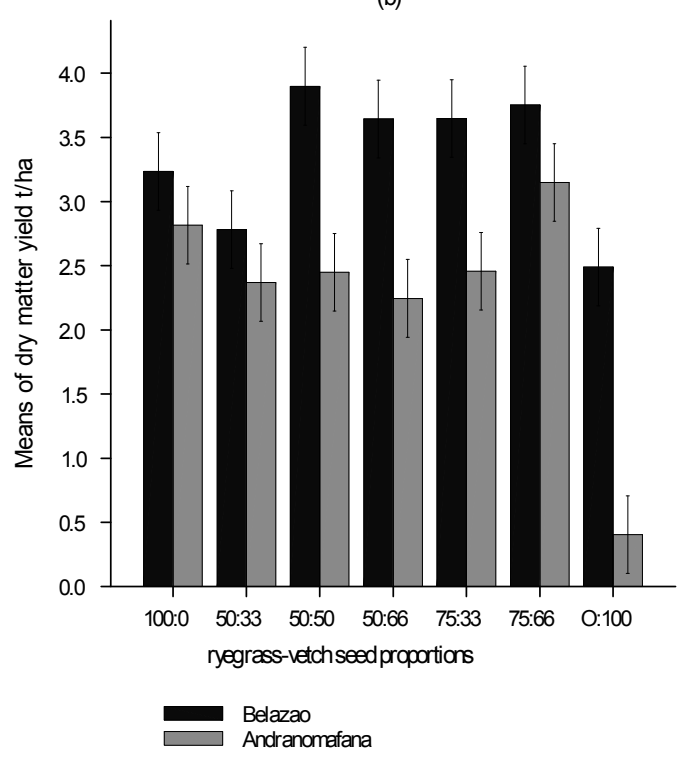

(d)

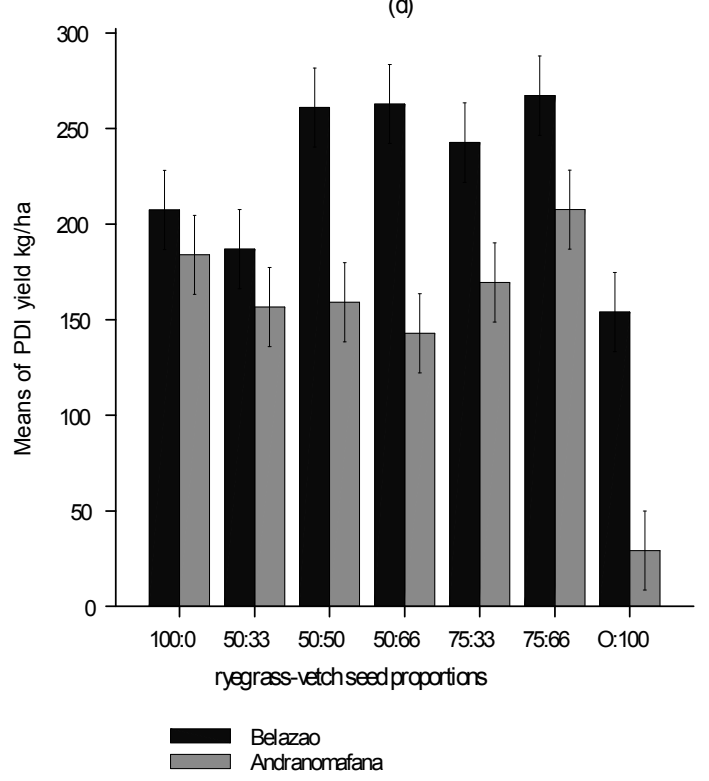

Figure 2. Means +/-e.s.e's for green matter yield (a): dry matter yield (b): feed unit for lactation yield (c): protein digested in the small intestine yield (d): at the two sites

UFL: feed unit for lactation, PDI: protein digested in the small intestine.

Regarding protein digested in the small intestine (PDI) yield, the site effect $(p=0.007)$ and the seed proportion effect $(\mathrm{p}<0.001)$ were significant (Table 1). At Belazao, all mixtures except the mixture of 50:33 gave slightly superior PDI yield than pure stands of either species but differences were not significant compared with pure stand of ryegrass (207.3 $\mathrm{kg} \mathrm{ha}^{-1}$ ) (Figure 2d). At Andranomafana, the mixture of 75:66 gave the maximum PDI yield $\left(207.5 \mathrm{~kg} \mathrm{ha}^{-1}\right)$ but the difference was not significant compared with the pure stand of ryegrass $(183.9 \mathrm{~kg}$ $\left.\mathrm{ha}^{-1}\right)$. According to the two site's results average, all mixtures except the mixture of 50:33 produced 3.6 to $21.3 \%$ more PDI yield than pure stand of ryegrass but the differences were not statistically significant (Table 2). 


\subsection{Forage Quality}

According to data averaged over the two sites, CF, TA, DM, PDIE and UFL contents did not vary significantly between seed proportions (Figure 3). The highest value (19.66 \% DM) for mean CF content was obtained from the mixture of 75:66 while the lowest value $(17.18 \% \mathrm{DM})$ from the pure stand of ryegrass. The highest mean TA value $(11.76 \% \mathrm{DM})$ was achieved by the mixture of $75: 33$ while the lowest mean TA value $(11.08 \% \mathrm{DM})$ by the mixture of 50:66. Mean DM content varied from $18.4 \%$ for pure stand of vetch to $21.96 \%$ for the mixture of $75: 66$. The lowest value ( 0.875 units $/ \mathrm{kg} \mathrm{DM})$ and the highest value $(0.915$ units $/ \mathrm{kg} \mathrm{DM})$ for mean UFL contents were obtained from pure stand of vetch and the mixture of 75:66, respectively. Mean PDIE content ranged from $64.7 \mathrm{~g} / \mathrm{kg} \mathrm{DM}$ for pure stand of ryegrass to $68.6 \mathrm{~g} / \mathrm{kg} \mathrm{DM}$ for mixture of $75: 66$.

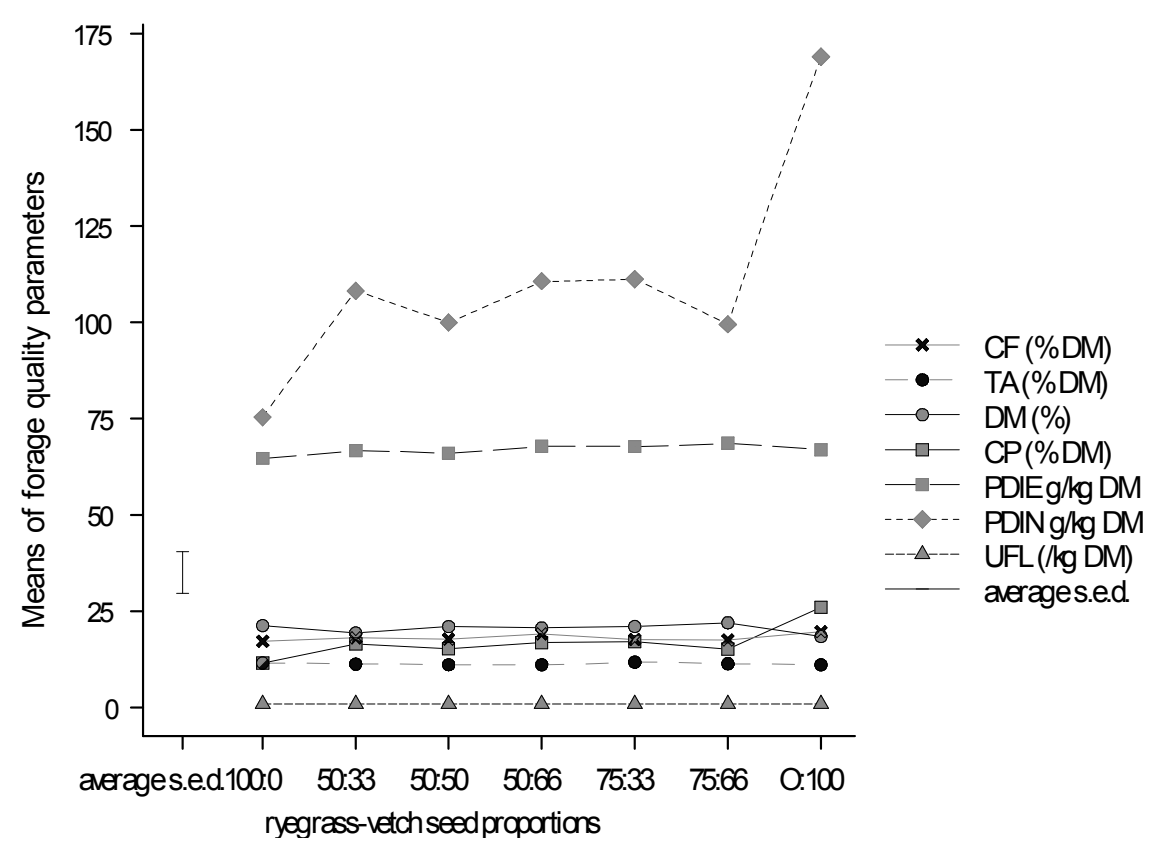

Figure 3. Mean +/-e.s.e's for quality parameters of the pure stands and mixtures of ryegrass-vetch CF: crude fibre, TA: total ash, DM: dry matter, CP: crude protein, PDIE: protein digested in the small intestine when rumen-fermentable energy is limiting, PDIN: protein digested in the small intestine when rumen-fermentable nitrogen is limiting, UFL: feed unit for lactation.

The mean CP and PDIN contents were affected by seed proportions. The highest mean CP content $(25.96 \%$ DM) was achieved by the pure stand of vetch while the lowest mean CP content (11.48\% DM) was obtained from the pure stand of ryegrass. Mean CP content increased 31 to $48 \%$ in mixtures compared to pure stand of ryegrass but the differences were not statistically significant. The lowest value $(75.3 \mathrm{~g} / \mathrm{kg} \mathrm{DM})$ for mean PDIN content was obtained from the pure stand of ryegrass while the highest value $(169.0 \mathrm{~g} / \mathrm{kg} \mathrm{DM})$ was obtained from pure stand of vetch. Mean PDIN content increased 32 to $47 \%$ in mixtures compared with pure stand of ryegrass but the differences were not also significant.

\subsection{Biological Compatibility}

Vetch rate in dry matter production increased with the increase of seed proportion of vetch in the mixture. Vetch contribution to dry matter yield ranged from 31 to $41 \%$ for the mixtures of 75:33 and 75:66, respectively. LER for dry matter yield of ryegrass in all mixtures (La) where higher than LER values for vetch (Lb). The combined LER values of all mixtures were greater than one (Table 3). The highest combined LER values 1.47 and 1.35 were recorded for the mixtures of 75:66 and 50:50, respectively. Higher competitive ratio (CRa) and positive aggressivity (Aa) values of ryegrass compared to $\mathrm{CR}$ and $\mathrm{A}$ values of vetch were recorded for all mixtures except the mixture of 75:33. 
Table 3. Competition indices of ryegrass-vetch mixtures for dry matter yield

\begin{tabular}{lcclll}
\hline Seed proportions & \multicolumn{1}{l}{ Vetch rate in dry matter yield $(\%) \mathrm{La}$} & $\mathrm{Lb}$ & \multicolumn{1}{l}{ LERAa } & $\mathrm{Ab}$ & $\mathrm{CRaCRb}$ \\
\hline $50 \%$ ryegrass-33\% vetch & 33 & 0.67 & 0.38 & 1.050 .002 & -0.0021 .150 .87 \\
$50 \%$ ryegrass-50\% vetch & 42 & 0.76 & 0.59 & 1.350 .003 & -0.0031 .290 .77 \\
$50 \%$ ryegrass-66\% vetch & 44 & 0.70 & 0.57 & 1.270 .005 & -0.0051 .620 .62 \\
$75 \%$ ryegrass-33\% vetch & 31 & 0.80 & 0.43 & $1.23-0.0020 .002$ & 0.821 .22 \\
$75 \%$ ryegrass-66\% vetch & 41 & 0.83 & 0.64 & 1.470 .002 & -0.0021 .160 .86 \\
\hline
\end{tabular}

$\mathrm{La}=$ land equivalent ratio for ryegrass, $\mathrm{Lb}=$ land equivalent ratio for vetch, $\mathrm{LER}=$ combined land equivalent ratio, $\mathrm{Aa}=$ aggressivity for ryegrass, $\mathrm{Ab}=$ aggressivity for vetch, $\mathrm{CRa}=$ competitive ratio for ryegrass, $\mathrm{CRb}=$ competitive ratio for vetch.

\section{Discussion}

At Belazao, slight increase of plant height for ryegrass in pure stand compared with mixtures could be associated with stronger intra-specific competition for resources under higher population density and nitrogen fertilizer applications. Higher plant heights for sole rice stand compared with intercropped rice at different levels of nitrogen fertilizer and different planting densities have been reported by Oroka (2011). Ryegrass height was significantly lower at Andranomafana. Plant height reduction could be related to the negative impacts of irrigation water shortages occurred at this site. However, significantly higher heights of intercropped ryegrass compared with ryegrass pure stand suggest complementary effects with vetch for limited growth factors supplies. Lower moisture content of soil in wheat-bean mixtures compared with pure stands of wheat at three sampling dates has been reported by Eskandari (2011). Moreover, higher plant heights of intercropped wheat compared with sole crops have been reported by Khan, Wahab and Rashid (2005).

Slight increase of ryegrass tiller numbers in mixtures compared with pure stand observed at both sites might reflect the complementary effects of ryegrass and vetch for efficient use of environmental resources. The mixture including the lowest seed proportions of either species (50:33) gave the highest ryegrass tiller numbers at both sites. This result suggests complementary effects through available spaces for horizontal growth and lesser inter-specific competition. Higher numbers of tillers/branches of cereal-vetch mixtures resulting from more number of tillers/branches in individual crops have been reported by Nadeem, Answar, Answar, Hussain and Khan (2010). The increase of ryegrass tiller numbers could justify the slightly increase of green matter and dry matter yields in mixtures compared with pure stand of ryegrass. Similar or significantly higher dry matter yields of mixtures compared with pure stands of either species have been reported in other studies (Rynolds, Sayre, \& Vivar, 1982; Ross, King, O’Donovant, \& Spaner, 2005; Lithourgidis et al., 2006).

Vetch proportion in dry matter yield reflected the sowing rates. Erol, Kaplan and Kizilsimsek (2009) found that the proportion of common vetch in dry forage was very similar to the seed proportion of common vetch in oat-vetch mixtures. The same findings have been reported in other studies (Karadag \& Büyükburç, 2003; Albayrak, Güler, \& Özgür Töngel, 2004).

Increased $\mathrm{CP}$ and PDIN contents were obtained from all mixtures compared with pure stand of ryegrass. Significantly higher protein yields of grass-legume mixtures resulting from increased dry matter yield and protein content have been reported in other studies (Chen, Westcott, Neill, Wichman, \& Knox, 2004; Erol et al., 2009). There was no consistency between CP and PDIN contents and vetch proportion at sowing. This is in contrast with the findings of Erol et al. (2009), who reported linear increase of CP concentration in the produced forage as vetch in the sowing mixture increased and Bande-Castro, Diaz Diaz, Fernández-Paz and Piňéiro-Andión (2010), who found a clear cut relationship between contribution of peas or vetch to yield and CP content.

The lack of significant effect of intercropping on protein content and protein yields of mixtures compared with pure stand of ryegrass observed in the present experiment could be related to stronger intra-specific competition following mineral nitrogen applications. It is worth noting that equal amounts of mineral nitrogen $\left(82 \mathrm{~kg} \mathrm{ha}^{-1}\right)$ had been applied to both pure stands and mixtures. Kunelius and Narasimhalu (1983) stated that when nitrogen was not applied to the ryegrass, the DM yields of ryegrass-legume mixtures outyielded those of monocultures. Erol et al. (2009) found that growing oat and common vetch in mixtures on a low-input basis, especially in terms of $\mathrm{N}$ fertilisation favoured the growth of common vetch resulting in yield advantages over pure stands. Thompson and Stout (1997) found that adding nitrogen fertilizer increased CP of ryegrass which was offset by 
reduced clover content. Moreover, Smith (1987) quoted that the incorporation of legumes into a ryegrass sward had the greatest positive effect on dry matter yields and CP content and yield when no nitrogen was applied and when harvested at 6-week intervals. Hence, lower nitrogen fertilizer application rates could have enhanced yield and improved forage quality through limitation of intra-specific competition and stimulation of biological nitrogen fixation and transfer by the vetch legume to ryegrass.

LER values for dry matter yield exceeding unity in all mixtures indicated yield advantage of intercropping compared with pure stands. The highest LER values obtained from the mixture of 75:66 (1.47) and 50:50 (1.35) indicated that 47 and $35 \%$ more areas would be required by a pure stand to achieve the same yield as these mixtures. Increased productivity of intercrops compared with sole crops has been reported in other studies (Karadag et al., 2003; Lithourgidis et al., 2006; Dhima et al., 2007, Erol et al., 2009; Rahetlah, Randrianaivoarivony, Razafimpamoa, \& Ramalanjaona, 2010; Atis et al., 2012). Partial LER ryegrass values (La) greater than 0.5 in all mixtures indicated advantage for ryegrass in intercropping. Positive values for ryegrass aggressivity index $(\mathrm{Aa})$ in all mixtures except for the mixture of 75:33 showed that ryegrass was the dominant species. However, aggressivity values of almost zero in all mixtures indicated mutual compatibility of the two combined species. The same trends were observed for competitive ratio. In all mixtures except for the mixture of 75:33, ryegrass $\mathrm{CR}$ values $(\mathrm{CRa})$ greater than one and ryegrass percentage in dry matter yield higher than the proportion of seed sown indicated that ryegrass was slightly more competitive than vetch. The dominant behaviour of grass over legume was also reported in other studies (Ghosh, 2004; Banik, Midya, Sarkar, \& Ghose, 2006).

\section{Conclusion}

The results obtained from this study show that intercropping of Italian ryegrass with common vetch has the potential to ensure mutual complementary effects for more efficient use of environmental resources as evidenced by increased yields and enhanced quality of forage produced. As mixtures composed of $75 \%$ ryegrass and $66 \%$ vetch or $50 \%$ ryegrass and $50 \%$ vetch gave the highest dry matter and protein yields, they could be recommended as sustainable alternatives to monoculture of ryegrass to alleviate dry season feed shortages in the highlands of Madagascar.

\section{Acknowledgments}

The present study was supported by the Royal Norwegian Embassy fund.

\section{References}

Adesogan, A. T., Salawu, M. B., \& Deaville, E. (2000). The effect on voluntary feed intake, in vivo digestibility and nitrogen balance in sheep of feeding grass silage or pea-wheat intercrops differing in pea to wheat ratio and maturity. Animal Feed Science and Technology, 96, 161-173. http://dx.doi.org/10.1016/S0377-8401(01)00336-4

Albayrak, S., Güler, M., \& Özgür Töngel, M. (2004). Effects of seed rates on forage production and hay quality of vetch-triticale mixtures. Asian Journal of Plant Sciences, 3(6), 752-756. http://dx.doi.org/10.3923/ajps.2004.752.756

AOAC (Association of Official Analytical Chemists). (1990). Official Methods of Analysis (7th ed.). USA.

Atis, I., Kokten, K., Hatipoglu, R., Yilmaz, S., Atak, M., \& Can, E. (2012). Plant density and mixture ratio effects on the competition between common vetch and wheat. Australian Journal of Crop Science, 6(3), 498-505

Balasubramanian, V., Ratsimandresy, J., Razafinjara, A. L., \& Rabeson, R. (1994). Phosphorous use efficiency in rice soils of the central highlands of Madagascar. In Transactions of the XV international congress of soil science (Vol. 5b, pp. 371-372). Acapulco, Mexico.

Bande-Castro, M. J., Diaz Diaz, N., Fernández-Paz, J., and Piňéiro-Andión, P. 2010. Yield and nutritive value of cereal-legume forage mixtures as an alternative to Italian ryegrass used as a winter crop in Galicia (NW Spain). Options Méditérranéennes, A (92), 125-128

Banik, P., Midya, A., Sarkar, B. K., \& Ghose, S. S. (2006). Wheat and chickpea intercropping systems in an additive series experiment: advantages and weed smothering. European Journal of Agronomy, 24, 325-332. http://dx.doi.org/10.1016/j.eja.2005.10.010

Bingol, N. T., Karsli, M. A., Yilmaz, H. I., \& Bolat, D. (2007). The effects of planting time and combination on the nutrient composition and digestible dry matter yield of four mixtures of vetch varieties intercropped with barley. Journal of Veterinary Animal Science, 31, 297-302. 
Buysse, W., Stern, R., \& Coe, R. (2004). Genstat Discovery Edition for everyday use. Nairobi: ICRAF.

Caballero, R., Goicoechea, E. L., \& Hernaiz, P. J. (1995). Forage yields and quality of common vetch and oat sown at varying seeding ratios and seeding rates of common vetch. Field Crop Research, 41, 135-140. http://dx.doi.org/10.1016/0378-4290(94)00114-R

Chen, C., Westcott, M., Neill, K., Wichman, D., \& Knox, M. (2004). Row configuration and nitrogen application for barley-pea intercropping in Montana. Agronomy Journal, 96, 1730-1738. http://dx.doi.org/10.2134/agronj2004.1730

Dhima, K.V., Lithourgidis, A.S., Vasilakoglou, I. B., \& Dordas, C. A. (2007). Competition indices of common vetch and cereal intercrops in two seeding ratio. Field Crop Research, 100, 249-256. http://dx.doi.org/10.1016/j.fcr.2006.07.008

Erol, A., Kaplan, M., \& Kizilsimsek, M. (2009). Oats (Avena sativa)-common vetch (Vicia sativa) mixtures grown on a low-input basis for a sustainable agriculture. Tropical Grasslands, 43, 191-196.

Eskandari, H. (2011). Intercropping of wheat (Triticum aestivum) and bean (Vicia faba): effects of complementarity and competition of intercrop components in resource consumption on dry matter production and weed growth. African Journal of Biotechnology, 17755-17762.

Ghosh, P. K. (2004). Growth, yield, competition and economics of groundnut/cereal fodder intercropping systems in the semi-arid tropics of India. Field Crops Research, 88, 227-237. http://dx.doi.org/10.1016/j.fcr.2004.01.015

Karadag, Y., \& Büyükburç, U. (2003). Effects of seed rates on forage production, seed yield and hay quality of annual legume-barley mixtures. Turkish Journal of Agriculture and Forestry, 27, 169-174.

Khan, M., Khan, R. U., Wahab, A., \& Rashid, A. (2005). Yield and yield components of wheat as influenced by intercropping of chickpea, lentil and rapeseed in different proportions. Pakistan Journal of Agricultural Sciences, 42, 3-4.

Kunelius, H. T., \& Narasimhalu, P. (1983). Yields and quality of Italian and westerwolds ryegrasses, red clover, alfalfa, birdsfoot trefoil, and Persian clover grown in monocultures and ryegrass-legume mixtures. Canadian Journal Plant Science, 63, 437-442. http://dx.doi.org/10.4141/cjps83-050

Lauk, R., \& Lauk, E. (2009). Dual intercropping of common vetch and wheat or oats, effects on yields and interspecific competition. Agronomy Research, 7(1), 21-32.

Lecomte, P., Duteurtre, G., \& Tillard, E. (2008). Mission exploratoire multidisciplinaire à Madagascar : valorisation des biomasses de couverture en intégrations agriculture élevage. Compte rendu de mission du 14 au 24 septembre, BVPI Sud Est/Hauts Plateaux.

Lithourgidis, A. S., Vasilakoglou, I. B., Dhima, K. V., Dordas, C. A., \& Yiakoulaki, M. D. (2006). Forage yield and quality of common vetch mixtures with oat and triticale in two seeding ratios. Field Crop Research, 99, 106-113. http://dx.doi.org/10.1016/j.fcr.2006.03.008

McGilchrist, C. A. (1965). Analysis of competition experiments, Biometrics. 21. 975-985. http://dx.doi.org/10.2307/2528258

Mead, R., \& Willey, R. W. (1980). The concept of land equivalent ratio and advantages in yields for intercropping. Experimental Agriculture, 16, 217-228. http://dx.doi.org/10.1017/S0014479700010978

Nadeem, M., Answar, M., Answar, A., Hussain, A., \& Khan, S. (2010). Performance of winter cereal-legumes fodder mixtures and their pure stand at different growth stages under rainfed conditions of pothowar. Journal of Agricultural Research, 48(2), 181-192.

Oroka, F. O. (2011). Responses of rice and cowpea intercropping to nitrogen fertilizer and plant population (2): vegetative growth and correlates of yield and yield components. Libyan Agriculture Research Center Journal Internation, 2(4), 174-179.

Raharimalala, J. (2002). Filière lait et production laitière à Madagascar. Antananarivo : MAEP.

Rahetlah, V. B., Randrianaivoarivony, J. M., Razafimpamoa L. H., \& Ramalanjaona V. L. (2010). Effects of seeding rates on forage yield and quality of oat (Avena sativa L.)-vetch (Vicia sativa L.) mixtures under irrigated conditions of Madagascar. African Journal of Food, Agriculture, Nutrition and Development, $10(10), 4254-4267$.

Rakotondramanana. (1999). Les grandes caractéristiques de la production laitière sur les Hautes Terres de 
Madagascar. In CIRAD-EMVT (Eds). Atelier sur les perspectives de développement de la production laitière en région chaude (pp.59-65). France.

Rasambainarivo, J. H., Razafindraibe, H., Rabehanitriniony, M., Rasoloarison, R., Rafalimanantsoa, E., \& Barsona, M. R. R. (2000). Responses to dry season supplementation by dairy cows on the highland zones of Madagascar. Final review meeting of AFRA Project II-17 (RAF/5/041), development and field evaluation of animal feed supplementation packages. Retrieved from www-naweb.iaea.org/nafa/aph/public/reports-3.pdf

Ross, S. M., King, J. R., O’Donovant, J. T., \& Spaner, D. (2005). The productivity of oat and berseem clover intercrops. I. Primary growth characteristics and forage quality at four densities of oat. Grass and Forage Science, 60, 74-86. http://dx.doi.org/10.1111/j.1365-2494.2005.00455.x

Rynolds, M. P., Sayre, K. D., \& Vivar, H. E. (1982). Intercropping wheat and barley with N fixing legume species: A method for improving ground cover, N-use efficiency and productivity in low input systems. Journal of Agricultural Science, 123, 175-183. http://dx.doi.org/10.1017/S002185960006843X

Smith, H. R. H. (1987). Identification of companion legumes for midmar Italian ryegrass. 1987. Journal of grassland society of southern Africa, 4(3), 100-104. http://dx.doi.org/10.1080/02566702.1987.9648081

Thompson, D. J., \& Stout D. G. (1997). Mixtures of Persian clover with Italian ryegrass or barley-Italian ryegrass for annual forage. Canadian Journal of Plant Science, 579-585. http://dx.doi.org/10.4141/P96-138

Vågen, T., Walsh, M. G., \& Shepherd, K. D. (2006). Stable isotopes for characterization of trends in soil carbon following deforestation and land use change in the highlands of Madagascar. Geoderma, 135, 133-139. http://dx.doi.org/10.1016/j.geoderma.2005.11.012

Whiteman, P. C. (1980). Tropical pasture science. New York: Oxford University Press.

Willey, R. M. (1979). Intercropping, its importance and research needs competition and yield advantages. Field Crop Abstracts, 32, 1-10.

Willey, R. W., \& Rao, M. R. (1980). A competitive ratio for quantifying competition between intercrops. Experimental Agriculture, 16, 117-125. http://dx.doi.org/10.1017/S0014479700010802

Yildirim, E., \& Guvence, I. (2005). Intercropping based on cauliflower: more productivity, profitable and highly sustainable. European Journal of Agronomy, 22, 11-18. http://dx.doi.org/10.1016/j.eja.2003.11.003 